\author{
Балян А. В. \\ д.е.н., академік НААН \\ віце-президент НААН України \\ Національна академія аграрних наук України \\ вул. Михайла Омеляновича-Павленка, 9, Київ, 01010 \\ E-mail:baliananush@gmail.com \\ ORCID ID: 0000-0003-2190-2022
}

\author{
Гришова І. Ю. \\ доктор економічних наук, професор \\ головний науковий співробітник \\ ННЦ «Інститут аграрної економіки» \\ вул. Героїв Оборони, 10, м. Київ, 03127 \\ E-mail: 2606147@ukr.net \\ ORCID ID: 0000-0001-6276-7619
}

Марчук л.л.

кандидат економічних наук

директор ПП «Аудиторська фрірма АФ Аудит-Експерт»

вул. Велика Арнаутська, буд. 15, пов.10, офріс 20/7, м. Одеса, Україна, 65048

E-mail: marchuk031972@ukr.net

ORCID ID: 0000-0002-7069-0751

\title{
МЕХАНІЗМ РЕАЛІЗАЦІЇ РЕГУЛЯТОРНОЇ ПОЛІТИКИ ЕКОНОМІЧНОЇ БЕЗПЕКИ В АГРАРНОМУ СЕКТОРІ УКРАЇНИ
}

У статті досліджується механізм реалізації регуляторної політики економічної безпеки аграрного виробництва, головною метою якого $є$ гарантування його стабільного й максимально ефективного ффункціонування в сучасних умовах та високого потенціалу інноваційного розвитку в довгостроковій перспективі та обґрунтовано головні положення функціонування даного механізму. Визначено систему заходів, що забезпечуватимуть реалізації регуляторної політики економічної безпеки аграрного виробництва. Досліджено соціальну складову економічної безпеки аграрного виробництва та механізм її функціонування. Також визначено заходи, щодо запобігання подальшому поглибленню руйнівних соціальних процесів в аграрному секторі та обґрунтовано основні напрями фоормування соціальної інфрраструктури. Формування ринку сучасної матеріально-технічної бази сільськогосподарського виробництва передбачає активний розвиток постачальницько-збутової мережі матеріально-технічних ресурсів аграрного виробництв. В зв'язку з цим важливого значення набувають напрями подальшого технічного переозброєння аграрних товаровиробників.

Ключові слова: економічна безпека, регуляторна політика, аграрне виробництво, соціальне забезпечення, матеріально-технічне забезпечення.

This work is licensed under a Creative Commons Attribution 4.0 International License http://creativecommons.org/licenses/by/4.0/

Постановка проблеми та їі зв'язок з важливими науковими та практичними завданнями. Беручи до уваги взаємовплив засобів державного регулювання та вимог і рекомендацій міжнародних правових інститутів на ефективність аграрного виробництва, середовища його функціонування у внутрішній й зовнішній конкурентній боротьбі, механізм реалізації регуляторної політики економічної безпеки має найефективнішим способом здійснювати вплив на всі сторони операційної діяльності суб'єктів сільськогосподарського виробництва за допомогою системи науково обгрунтованих державних соціальноекономічних критеріїв, норм, нормативів та через систему ринкових важелів.

Система державного регулювання забезпечення економічної безпеки аграрного виробництва представляе собою комплекс організаційнотехнічних, соціально-економічних, наукових й політичних умов функціонування продуктивних сил та виробничо-господарських відносин, які взаємодіючи впливають на рівень економічної безпеки. Метою регуляторної політики економічної безпеки аграрного виробництва $\epsilon$ забезпечення населення продуктами харчування, іншими товарами з сільськогосподарської сировини, а також вирішення соціальноекономічних проблем аграрного сектору в умовах становлення ринкових відносин.

Аналіз останніх публікацій по проблемі. Механізми реалізації регуляторної політики економічної безпеки аграрного виробництва розглядаються провідними вітчизняними вченими-економістами, зокрема: Гейця В.М., Балян А.В., Василина О.Р., Гришової І.Ю., Дяченко О.П, Зеліско Н.Б., Лупенко Ю.О., Ніколюк О.В., Русан В.М., Саблук П.Т., Утенкова К.О. та багатьох інших.

У працях науковців Ніколюк О.В. та Русан В.М. досліджуються теоретичні основи використання дефініції "економічна безпека" та інституційних засад розвитку аграрного сектору у контексті забезпечення економічної безпеки держави $[1,2]$. Важливого значення в питаннях економічної безпеки займає боротьба $з$ проявами тіньової економіки, що набуває 
загрозливих масштабів, особливо в аграрному секторів, на що вказує Дяченко О.П. [3]. Аналіз теоретикометодичних засад регулювання рівня економічної безпеки у розрізі окремих функціональних складових досліджує Утенкова К.О. та пропонує механізм регулювання фінансової безпеки підприємства, який повинен формуватися як складова системи управління економічною безпекою підприємства у цілому шляхом використання певних принципів, важелів, інструментів, методів забезпечення [4].

Методологію визначення економічної безпеки та іiі місця в загальній стратегії функціонування підприємства досліджують Зеліско Н.Б., Василина O.P. [5].

Формулювання цілей дослідження. Мета дослідження - дослідження та формування механізму реалізації регуляторної політики економічної безпеки аграрного виробництва. Методологія здійсненого дослідження грунтується на системно-комплексному та синергетичному підходах, що має на меті проведення теоретичних досліджень в основних аспектах теми дослідження.

Виклад основних результатів та їх обгрунтування. Для обгрунтування змісту механізму реалізації регуляторної політики економічної безпеки аграрного виробництва, зазначимо, що господарський механізм складається 3 сукупності організаційноінституційних структур і конкретних форм, методів, інструментів та нормативно-правових норм за допомогою яких держава додержується об'єктивних вимог економічних законів. У свою чергу, механізм реалізації регуляторної політики економічної безпеки аграрного виробництва $\epsilon$ функціональноінституціональним способом організації взаємодії елементів соціально-економічної системи 3 метою іiі координації та управління у напрямку забезпечення реалізації національних інтересів, запобігання загрозам економічної безпеки, нейтралізації їх наслідків та досягнення на цій основі такого рівня економічної безпеки аграрного виробництва, який би ефективно сприяв виконанню цілей розвитку національної економіки (рис. 1).

До функцій механізму реалізації регуляторної політики економічної безпеки аграрного виробництва належать: створення організаційноінституційних та нормативно-правових засад для побудови, функціонування та розвитку системи забезпечення економічної безпеки аграрного виробництва; прогнозування, виявлення та оцінка можливих загроз економічній безпеці аграрного виробництва; участь у міжнародних, національних системах економічної безпеки (розробка і прийняття відповідної нормативно-правової бази, яка регулює міждержавні та національні відносини щодо економічної безпеки в аграрному виробництві).

Механізм реалізації регуляторної політики економічної безпеки аграрного виробництва містить в собі інституції державного регулювання та інституції ринкового середовища та їх вплив на соціальноекономічні процеси, які мають місце в аграрному виробництві [7].

Головними положеннями функціонування механізму реалізації регуляторної політики економічної безпеки аграрного виробництва можна вважати наступні:

1) механізм реалізації регуляторної політики економічної безпеки аграрного виробництва грунтується на системному підході, що об'єднує рекомендації міжнародних нормативних актів, ринкові механізми, засоби державного регулювання та складові виробничо-господарської діяльності у їх тісному взаємозв'язку;

2) у механізм реалізації регуляторної політики економічної безпеки аграрного виробництва включаються різні режими регулювання - від традиційного до режиму повної лібералізації;

3) виробничо-господарська та комерційномаркетингова діяльність суб'єктів аграрного виробництва адаптується до режимів регулювання й до існуючої кон'юнктури ринку;

4) поступовий перехід від традиційного до інших режимів регулювання відбувається поетапно, враховуючи зміни параметрів попиту і пропозиції, ринкового ціноутворення, перманентного конкурентного середовища у контексті оцінки ефективності функціонування аграрного виробництва у ринкових умовах;

5) узгодження соціально-економічних інтересів держави, виробників аграрної продукції та споживачів.

Головною метою механізму реалізації регуляторної політики економічної безпеки аграрного виробництва $\epsilon$ формування умов, в яких аграрне виробництво може розвиватися стабільним, економічно ефективним шляхом із забезпеченням високого рівня економічної та еколого-техногенної безпеки у контексті дотримання соціально-трудових стандартів для сільського населення.

Механізм реалізації регуляторної політики економічної безпеки аграрного виробництва враховує особливості входження України до СОТ, які вплинули на зміну підходів до регулювання: від стійкого державного регулювання - до активізації на ринкові сили. Менш регламентоване економічне середовище дає аграрним виробникам більше комерційної свободи та гнучкості, однак, у свою чергу, розширює можливості для використання антиконкурентної практики $[8,9]$.

Саме тому, попередження та контроль зловживань, в тому числі тінізація грошових потоків, в умовах лібералізації ринку, є ключовою проблемою як державних органів, так і відповідних структур на рівні аграрного виробництва, що вимагають кардинальних заходів по протидії незаконним оборудкам [3]. Стабільність функціонування аграрного виробництва та гарантія якісної продукції вимагають формування у рамках механізму реалізації регуляторної політики економічної безпеки аграрного виробництва, умов для створення середовища сумлінної конкуренції всім учасникам ринку.

Отже, державна політика має виконувати завдання щодо створення сучасної галузі виробництва, яка забезпечить формування повної потреби харчових продуктів. 


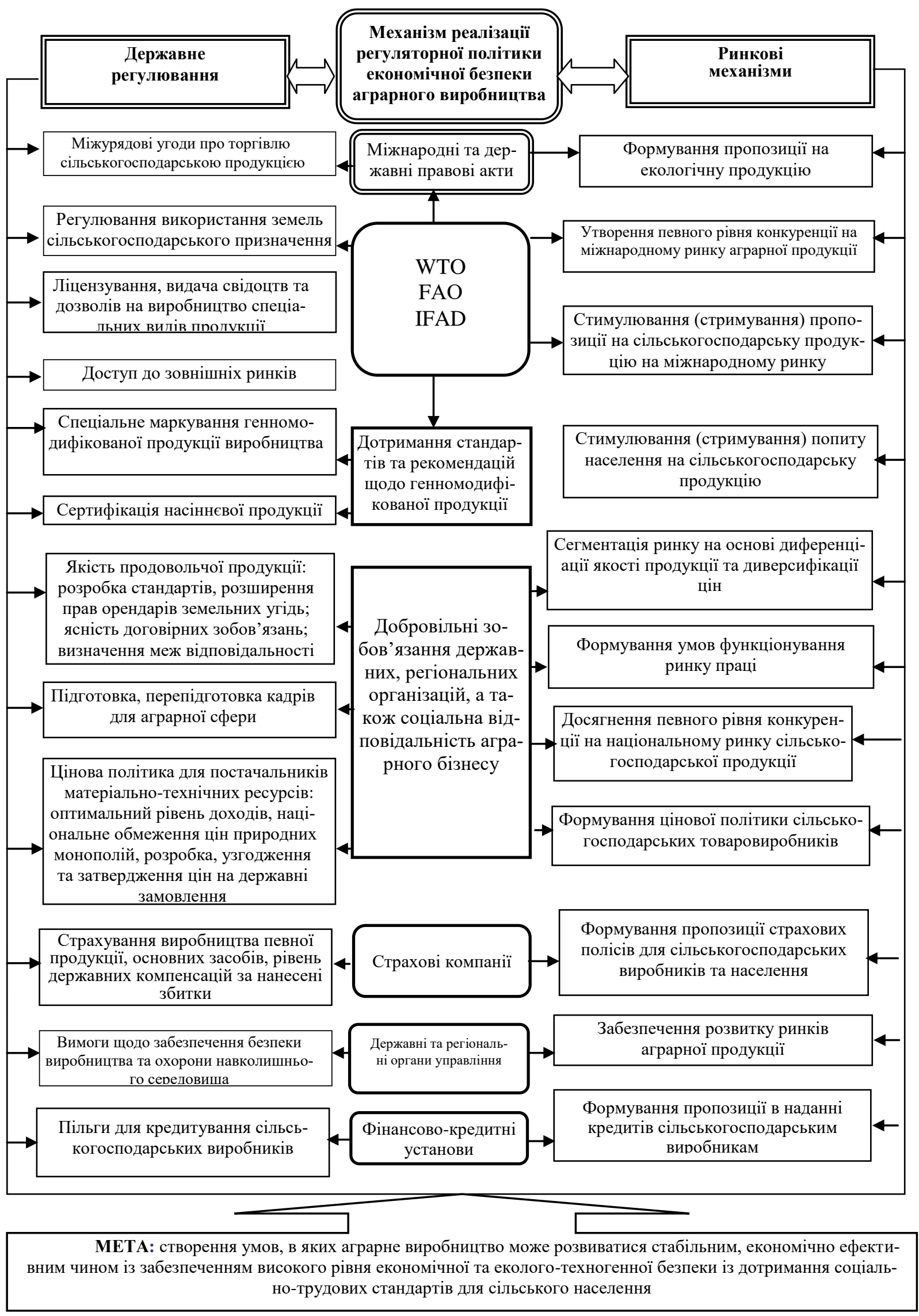

Рис. 1. Механізм реалізації регуляторної політики економічної безпеки аграрного виробництва в Україні*

* розроблено авторами за [6-9] 
Важливим напрямом організації виробничогосподарської діяльності у сфері нарощування продуктів харчування й збільшення випуску сільськогосподарської сировини для переробної галузі має стати широке використання виробничої кооперації та вертикальної інтеграції, формування високотехнологічних професійних холдингових об'єднань і корпоративних структур. На базі великих сільських поселень необхідно розвивати спеціалізовані агломерації, в яких поєднуватимуться великі зони територіального виробництва відповідних видів сільськогосподарської продукції (цукрових буряків, олійних культур, зернових тощо), формуватимуться сектори їі заготівлі, зберігання і промислової переробки та реалізації.

На наш погляд, для забезпечення безпечного розвитку аграрного виробництва в Україні потрібний ефективних фінансовий механізм, який розглядається нами як підсистема загального механізму реалізації регуляторної політики економічної безпеки аграрного виробництва. Ситуація, що склалася в Україні, вимагає перебудови організації кредитних відносин: удосконалення тих, що $є$ і розробка нових механізмів. Вирішення цієї проблеми обумовлює необхідність активізації вивчення теорії і практики короткострокового кредитного обслуговування суб'єктів аграрного виробництва.

В умовах, що склалися, варто запозичити позитивний досвід високорозвинутих країн, щодо об'єднання груп сільгоспвиробників, переробних підприємств i торгових організацій в міжгалузеві об'єднання. Ці об'єднання стануть ефективною формою співпраці в сфері аграрного виробництва, переробки і реалізації продукції з метою збільшення загального обороту в закупівлі і реалізації, уникнення індивідуальними виробниками ризиків від коливання цін на ринку, гарантування членам групи стабільних середніх цін на їх продукцію, виходу на нові ринки збуту, зменшення непродуктивних витрат, проведення загального маркетингу, гарантування оплати за продукцію в певні терміни, сприяння розвитку виробництва продукції і матеріально-технічної бази суб'єктів аграрного виробництва [5].

Для реалізації регуляторної політики економічної безпеки аграрного виробництва було розроблено систему заходів (рис. 2).

У рамках нашого дослідження особливу увагу приділено соціальній складовій економічної безпеки аграрного виробництва, механізм функціонування якої передбачає: поступове підвищення частки заробітної плати в структурі собівартості продукції; сприяння легалізації «тіньових» заробітних плат, що збільшить нагромаджену частину пенсійних фондів; введення державного страхування ризиків кредитування, що полегшить умови кредитування; встановлення більш вигідних умов усіх видів страхування; реформування системи надання соціальних пільг; впровадження моделі розрахунку соціального бюджету; державне сприяння формуванню середнього класу в країні.

Запобігання подальшому поглибленню руйнівних соціальних процесів в аграрному секторі пе- редбачає поступове втілення в життя комплексу нормативно-правових i організаційно-інституційних та соціально-економічних заходів. Такі заходи повинні грунтуватись на реальному попиті та пропозиції соціальних послуг безпосередньо на рівні господарюючого суб'єкта, посилення регулювального впливу держави, органів місцевого самоврядування на засадах діалектичного поєднання функцій місцевих владних структур із регіональними й загальнодержавними органами влади. У цьому контексті основними напрямами формування соціальної інфраструктури як сукупності структурних елементів сільських поселень для забезпечення сільським жителям належних умов праці та відпочинку й формування комфортного життєвого середовища варто визнати:

- активізація децентралізації управлінських функцій держави на користь місцевого самоврядування, здійснення чіткого розмежування функцій i повноважень центральних та місцевих органів виконавчої влади щодо розвитку аграрного сектору та сільських територій;

- забезпечення реального самоуправління на рівні територіальних громад шляхом законодавчого й фінансового врегулювання формування місцевих бюджетів і контролю за їх виконанням;

- удосконалення на законодавчому рівні міжбюджетних відносин центральних та місцевих органів виконавчої влади, зокрема тих, що пов'язані з вирішенням питань фінансування проектів комплексного розвитку аграрного виробництва та сільських територій;

- розробка та впровадження дієвої нормативно-правової бази, єдиних стандартів і нормативів соціального обслуговування, обгрунтування фінансового механізму щодо формування місцевих бюджетів та гарантій участі держави у соціальній розбудові села;

- визначення пріоритетів соціальної розбудови на рівні кожного адміністративно-територіального утворення;

- активізація залучення коштів суб'єктів господарювання, установ та організацій для розбудови соціальної сфери на добровільній основі тощо [4].

Реалізація таких заходів щодо розвитку соціальної сфери, в основі яких знаходяться соціальні цілі економічних реформ у напрямку забезпечення соціального захисту та соціальних гарантій населенню, що дасть можливість підвищити рівень економічної безпеки країни $[10,11]$.

Стратегічною метою реформування соціальної сфери є формування соціально-орієнтованої економіки, вирівнювання пропорцій економічного й соціального розвитку сільських територій, зосередженого на інтересах громади села, їі кожного жителя, створення у сільських поселеннях належних умов праці та проживання. Отже, існує нагальна потреба в розробці основних підходів до формування стану економічної безпеки у вимірі людського розвитку 3 таким розрахунком, щоб забезпечити більш високий рівень економічної безпеки, раціональне використання іiі потенціалу і високу конкурентну спроможність господарюючих суб'єктів. 
Заходи реалізації регуляторної політики економічної безпеки аграрного виробництва в Україні

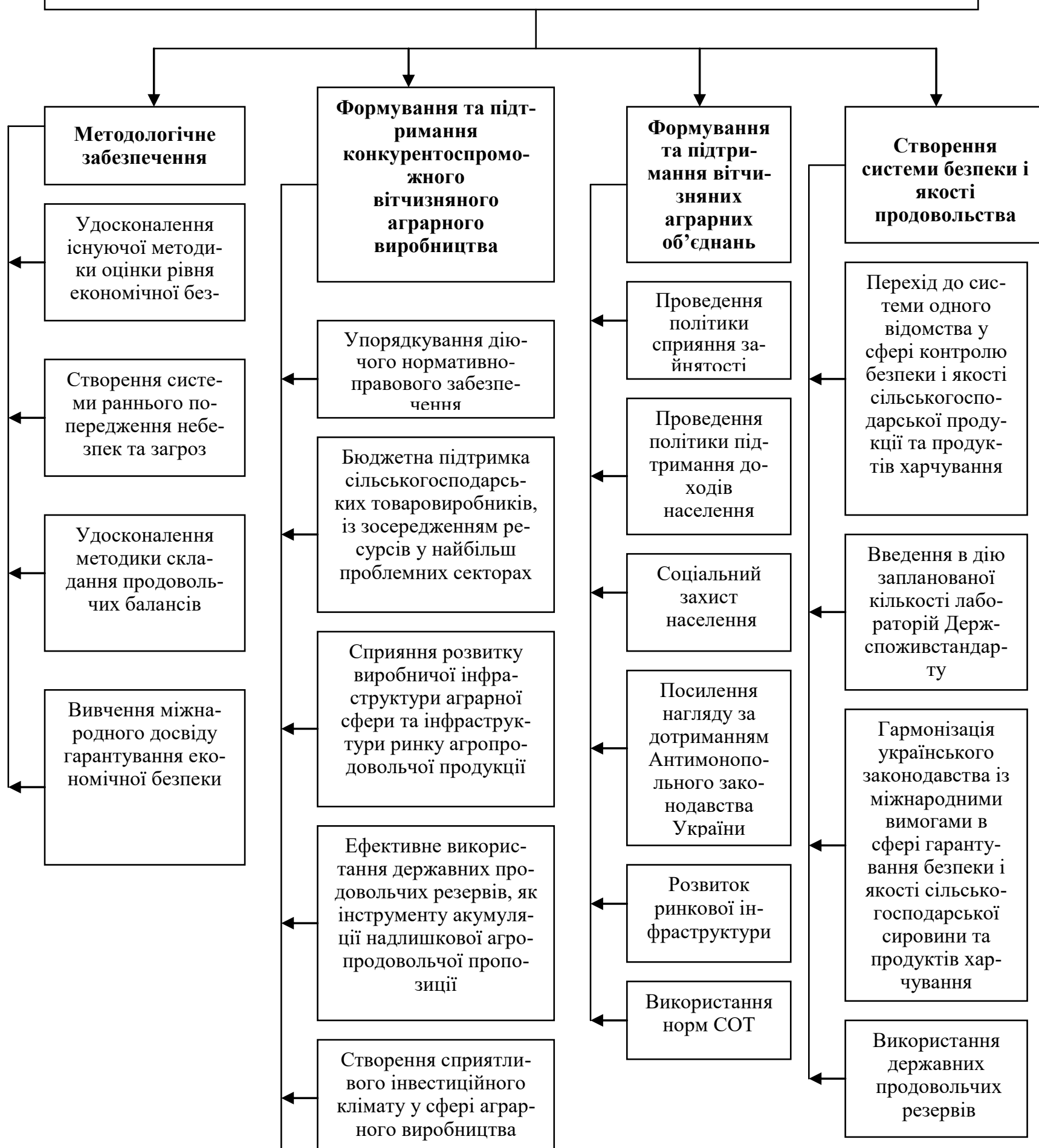

Сприяння інституційному розвитку агропродовольчого сектору економіки

Рис. 2. Система заходів реалізації регуляторної політики економічної безпеки аграрного виробництва

* запропоновано авторами [6-9] 
Отже, посилення соціальної складової економічної безпеки аграрного виробництва передбачає:

- підвищення життєвого рівня населення, насамперед, на основі підвищення оплати праці, своєчасної виплати заробітної плати й гарантованих законом соціальних виплат, посилення цільової спрямованості матеріальної підтримки, зниження рівня безробіття;

- формування умов для подолання бідності й надмірного розмежування в суспільстві;

- збереження та зміцнення демографічного й трудового потенціалу;

- подолання кризових демографічних процесів;

- створення ефективної системи соціального захисту людей, охорони й відновлення їхнього фізичного і духовного здоров'я тощо.

Для виведення виробничо-господарського сектору аграрного виробництва 3 стану небезпеки доцільним є:

- вдосконалення діючого механізму забезпечення економічної безпеки аграрного виробництва;

- розвиток виробничої, соціальної та збутової інфраструктури ринку аграрної продукції з метою ліквідації посередницьких структур;

- поглиблення спеціалізації сільськогосподарських підприємств;

- розвиток науково обгрунтованих систем землеробства і сівозмін;

- стимулювання розвитку великотоварних багатогалузевих господарств;

- розробка заходів щодо формування міжгалузевих об'єднань товаровиробників аграрного виробництва;

- покращення умов кредитування інноваційних технологій виробництва аграрної продукції тощо.

Так як подальший розвиток аграрного виробництва нерозривно пов'язаний 3 його технікотехнологічним переозброєнням, тому особливе місце в ньому належить питанням формування ринку матеріально-технічних ресурсів аграрного виробництва. Світовий досвід підтверджує, що одним із напрямів розвитку ринку матеріально-технічних ресурсів, послуг постачання, ремонту і технічного обслуговування $€$ формування розгалуженої й керованої товарообмінної мережі дилерських центрів, виробничо-технічних або постачальницько-збутових кооперативів, завдяки яким виробники зможуть реалізовувати і надавати технічний сервіс машинно-тракторного парку. Так, у США поряд із незалежною дилерською мережею, виробники мають і мережу збутових систем дилерського типу. Фірма «John Deer» має власні складські комплекси в різних регіонах країни.
Тому вважаємо, що агротехнічне обслуговування потрібно розглядати в тісному взаємозв'язку з виробництвом i споживанням техніки. Аналогічні об'єднання діють і в Польщі (регіональні машиннотехнічні станції). Отже, формування дилерських мереж дасть змогу значно скоротити витрати на технічне обслуговування, зменшить час простоїв машин, підвищить ефективність використання сільськогосподарської техніки, а також сприятиме налагодженню прямих зв'язків із заводами-виробниками, що нівелює роль комерційних посередників, які наживаються на угодах купівлі-продажу.

Висновки та перспективи подальших досліджень. Наукова новизна одержаних результатів полягає в системному підході до вирішення важливої проблеми - вдосконалення регуляторної політики щодо забезпечення економічної безпеки аграрного виробництва в Україні. Наукові положення щодо формування структури механізму реалізації регуляторної політики економічної безпеки аграрного виробництва, які на відмінну від наявних, включають комплексну впорядковану сукупність функціональних компонент та елементів (фінансово-економічних, інноваційних, нормативно-правових, інформаційних, соціально-екологічних, контролюючих), що сприяє обгрунтуванню принципів, методів, інструментів i засобів, які забезпечують реалізацію тактичних та стратегічних орієнтирів регуляторної політики економічної безпеки аграрного виробництва.

Отже, механізм реалізації регуляторної політики економічної безпеки аграрного виробництва $\epsilon$ функціонально-інституціональним способом організації взаємодії елементів соціально-економічної системи з метою її координації та управління у напрямку забезпечення реалізації національних інтересів, запобігання загрозам економічної безпеки, нейтралізації їх наслідків та досягнення на цій основі такого рівня економічної безпеки аграрного виробництва, який би ефективно сприяв виконанню цілей розвитку національної економіки. До функцій механізму реалізації регуляторної політики економічної безпеки аграрного виробництва належать: створення організаційноінституційних та нормативно-правових засад для побудови, функціонування та розвитку системи забезпечення економічної безпеки аграрного виробництва; прогнозування, виявлення та оцінка можливих загроз економічній безпеці аграрного виробництва; участь у міжнародних, національних системах економічної безпеки (розробка і прийняття відповідної нормативно-правової бази, яка регулює міждержавні та національні відносини щодо економічної безпеки в аграрному виробництві).

\section{Література}

1. Ніколюк О.В. Теоретико-методологічні засади інституційного регулювання соціально-економічної безпеки аграрного виробництва: монографія. Одеса: Друкарський дім, Друк Південь, 2018. 298 с.

2. Русан В.М., Дяченко О.П. Інституційні засади розвитку аграрного сектору у контексті забезпечення економічної безпеки держави // Наукові записки Інституту законодавства Верховної Ради України. 2019. №2. С. 117-122. doi: 10.32886/instzak.2019.02.12 
3. Дяченко О.П. Основні напрями та етапи державної політики протидії розвитку тіньової економіки в Україні // Інвестиції: практика і досвід. 2018. №1. С. 104-107.

4. Утенкова К.О. Регулювання економічної безпеки підприємств аграрного сектору // Modern economics. 2020. № 20. C. 278-285. doi: 10.31521/modecon.V20(2020)-43

5. Зеліско Н.Б., Василина О.Р. Оцінка гарантування економічної безпеки аграрних підприємств // Вчені записки Таврійського національного університету імені В. І. Вернадського. Сер. Економіка і управління. 2020. T. 31(70), № 2(1). C. 196-200. . doi: 10.32838/2523-4803/70-2-32

6. Gryshova I., Nikoliuk O., Marchuk L. Institutional aspects of the regulation of economic security of the agricultural production // Food Industry Economics. 2019. Vol.11, Issue 3. P. 23-32. doi: 10.15673/fie.v11i3.1458.

7. Концепція економічної безпеки України. Кер. проекту В. М. Геєць; Ін-т економічного прогнозування. К.: Логос, 1999. С. 129.

8. Gryshova I., Kyzym M., Hubarieva I., Khaustova V., Livinskyi A., Koroshenko M. Assessment of the EU and Ukraine Economic Security and Its Influence on Their Sustainable Economic Development // Sustainability. 2020. Volume 12, P.7692. doi: 10.3390/su12187692

9. Ніколюк О.В., Лівінський А.І. Стратегічний аспект формування регуляторної політики соціальноекономічного розвитку аграрного виробництва // Економічний аналіз: зб. наук. праць / Тернопільський національний економічний університет. Тернопіль: Видавничо-поліграфічний центр Тернопільського національного економічного університету «Економічна думка», 2018. Том 28. № 1. С. 303-310.

10. Балян А.В. Гришова І.Ю. Пріотитети екологічної безпеки в аграрній політиці в контексті сіпвробітництва України та Китаю // Zbiór artykułów naukowych z Konferencji Miedzynarodowej Naukowo Praktycznej (online) zorganizowanej dla pracowników naukowych uczelni, jednostek naukowo-badawczych oraz badawczych z państw obszaru byłego Związku Radzieckiego oraz byłej Jugosławii (30.06.2020) - Warszawa, 2020. P. 33-37

11. Ніколюк О.В., Лівінський А.І. Оцінка стану соціально-економічного розвитку аграрного виробництва в Україні // Економічний аналіз: зб. наук. праць / Тернопільський національний економічний університет. Тернопіль: Видавничо-поліграфічний центр Тернопільського національного економічного університету «Економічна думка», Том 28. №2, C.42-48.

12. Мищак I. М., Гришова Р. В. Законопроект про внесення змін до Конституції України (щодо децентралізації влади): дискусійні положення // Законодавчі аспекти модернізації публічного управління та адмінстрування в Україні. Сер. Законодавчі аспекти державного управління та місцевого самоврядування / Заг ред. О.Л. Копиленка, В.С. Воротіна. К.: Вид-во «Людмила», 2020. Вип. 4. С.67-77. doi: 10.32886/instzak.2020.01.06

Стаття надійшла 9.02.2021 Стаття прийнята до друку 23.02.2021 Доступно в мережі Internet 18.04.21

Balian A.

Doctor of Economics, Academician of NAAS, Vice-President of NAAS of Ukraine National Academy of Agrarian Sciences of Ukraine Str. Omelianovych-Pavlenko, 9, Kyiv, Ukraine, 01010 E-mail: baliananush@gmail.com ORCID ID: 0000-0003-2190-2022

\section{Gryshova I.}

Doctor of Economics,, Professor Chief Researcher

National Research Center "Institute of Agrarian Economics"

Str. Heroes of Defense, 10, Kyiv, Ukraine, 03127

E-mail: 2606147@ukr.net

ORCID ID: 0000-0001-6276-7619

\section{Marchuk L. $\mathrm{PhD}$}

Director of PE "AUDIT FIRM AUDIT-EXPERT"

Str.Velyka Arnautska, 15, floor 10, office 20/7, Odessa, Ukraine, 65048

E-mail: marchuk031972@ukr.net

ORCID ID: 0000-0002-7069-0751

\section{MECHANISM OF IMPLEMENTATION OF REGULATORY POLICY OF ECONOMIC SAFETY OF AGRICULTURAL PRODUCTION IN UKRAINE}

The article examines the mechanism of implementation of regulatory policy of economic security of agricultural production, the main purpose of which is to ensure its stable and most effective operation in modern conditions and high potential for innovative development in the long run and substantiates the main provisions of this mechanism. A system of measures has been identified to ensure the implementation of the regulatory policy of economic security of agricultural production. Measures to prevent further deepening of destructive social processes in the agricultural sector have also been identified and the main directions of social infrastructure formation have been substantiated. The formation of the market of modern material and 
technical base of agricultural production involves the active development of the supply and marketing network of material and technical resources of agricultural production. The social component of economic security of agricultural production and the mechanism of its functioning have been investigated. It has been established that the mechanism of implementation of regulatory policy of economic security of agricultural production is a functional and institutional way of organizing the interaction of elements of socio-economic system in order to coordinate and manage it in the direction of national interests, prevention of threats to economic security, neutralization of their consequences, levelling of economic security of agricultural production, which would effectively contribute to the goals of the national economy. The functions of the mechanism for implementing the regulatory policy of economic security of agricultural production include: creation of organizational and institutional and regulatory framework for the construction, operation and development of the system of economic security of agricultural production; forecasting, identification and assessment of possible threats to the economic security of agricultural production; participation in international, national systems of economic security (development and adoption of the relevant regulatory framework governing interstate and national relations on economic security in agricultural production). In this regard, the areas of further technical re-equipment of agricultural producers are becoming important.

Key words: economic security, regulatory policy, agricultural production, social security, logistics.

\section{References}

1. Nikoliuk, O. V. (2018). Teoretyko-metodolohichni zasady instytutsiinoho rehuliuvannia sotsialnoekonomichnoi bezpeky ahrarnoho vyrobnytstva. Odesa: Drukarskyi dim, Druk Pivden.

2. Rusan, V. M., \& Diachenko, O. P. (2019). Instytutsiini zasady rozvytku ahrarnoho sektoru u konteksti zabezpechennia ekonomichnoi bezpeky derzhavy. Naukovi zapysky Instytutu zakonodavstva Verkhovnoi Rady Ukrainy, (2), 2019, 117-122. doi: 10.32886/instzak.2019.02.12

3. Diachenko, O. P. (2018). Osnovni napriamy ta etapy derzhavnoi polityky protydii rozvytku tinovoi ekonomiky v Ukraini. Investytsii: praktyka i dosvid, (1), 104-107.

4. Utenkova, K. O. (2020). Rehuliuvannia ekonomichnoi bezpeky pidpryiemstv ahrarnoho sektoru. Modern economics, (20), 278-285. doi: 10.31521/modecon.V20(2020)-43

5. Zelisko, N. B., \& Vasylyna, O. R. (2020). Otsinka harantuvannia ekonomichnoi bezpeky ahrarnykh pidpryiemstv. Vcheni zapysky Tavriiskoho natsionalnoho universytetu imeni V. I. Vernadskoho, 31(70)(2(1), 196-200. doi: $10.32838 / 2523-4803 / 70-2-32$

6. Gryshova, I., Nikoliuk, O., \& Marchuk, L. (2019). Institutional aspects of the regulation of economic security of the agricultural production. Food Industry Economics, 11(3), 23-32. doi: 10.15673/fie.v11i3.1458.

Kyiv: Lohoc.

7. Heiets, V. M. (1999). Kontseptsiia ekonomichnoi bezpeky Ukrainy. In-t ekonomichnoho prohnozuvannia.

8. Gryshova, I., Kyzym, M., Hubarieva, I., Khaustova, V., Livinskyi, A., \& Koroshenko, M. (2020). Assessment of the EU and Ukraine Economic Security and Its Influence on Their Sustainable Economic Development. Sustainability, 12, 7692. doi: 10.3390/su12187692

9. Nikoliuk, O. V., \& Livinskyi, A. I. (2018). Stratehichnyi aspekt formuvannia rehuliatornoi polityky sotsialno-ekonomichnoho rozvytku ahrarnoho vyrobnytstva. Zb. nauk. prats. In Ekonomichnyi analiz (1st ed., Vol. 28, 303310). Ternopil; Vydavnycho-polihrafichnyi tsentr Ternopilskoho natsionalnoho ekonomichnoho universytetu «Ekonomichna dumka».

10. Balian, A. V., \& Hryshova, I. Yu. (2020). Priotytety ekolohichnoi bezpeky v ahrarnii politytsi v konteksti sipvrobitnytstva Ukrainy ta Kytaiu. In Zbiór artykułów naukowych z Konferencji Miedzynarodowej Naukowo Praktycznej (on-line) zorganizowanej dla pracowników naukowych uczelni, jednostek naukowo-badawczych oraz badawczych z państw obszaru byłego Związku Radzieckiego oraz byłej Jugosławii (pp. 33-37). Warszawa.

11. Nikoliuk, O. V., \& Livinskyi, A. I. (2018). Otsinka stanu sotsialno-ekonomichnoho rozvytku ahrarnoho vyrobnytstva v Ukraini. Zb. nauk. prats. In Ekonomichnyi analiz (2st ed., Vol. 28, 42-48). Ternopil: Vydavnychopolihrafichnyi tsentr Ternopilskoho natsionalnoho ekonomichnoho universytetu «Ekonomichna dumka».

12. Myshchak, I. M., \& Hryshova, R. V. (2020). Zakonoproekt pro vnesennia zmin do Konstytutsii Ukrainy (shchodo detsentralizatsii vlady): dyskusiini polozhennia (O. L. Kopylenko \& V. Ye. Vorotin, Eds.). Zakonodavchi Aspekty Modernizatsii Publichnoho Upravlinnia Ta Adminstruvannia $v$ Ukraini, (4), 67-77. doi: 10.32886/instzak.2020.01.06

Цитування згідно ДСТУ 8302:2015

Received 9 February 2021

Approved 23 February 2021

Available in Internet 18.04.2021

Балян А.В., Гришова І.Ю., Марчук Л.Л. Механізм реалізації регуляторної політики економічної безпеки в аграрному секторі України // Економіка харчової промисловості. 2021. Т.13, вип. 1. С.82-89.

Cite as APA style citation

Balyan, A., Gryshova, I., \&Marchuk, L. (2021). Mechanism of implementation of regulatory policy of economic safety of agricultural production in Ukraine. Food Industry Economics, 13(1), 82-89. 